\title{
Knowledge Sharing Among Accounting Students: An Exploratory Study*
}

\author{
Omer Ali BAGAIS ${ }^{1}$, Khaled Salmen ALJAAIDI², Ehsan Saleh AL-MOATAZ ${ }^{3}$ \\ Received: August 01, 2020 Revised: September 06, 2020 Accepted: October 05, 2020
}

\begin{abstract}
This paper explores the attitudes of accounting students toward knowledge sharing at Umm Al-Gura University for the academic year 2013-2014. The study explored knowledge sharing among 202 accounting students at Umm Al-Gura University in session during the 20132014 academic year. Primary data came from a 3-item questionnaire collected from students; secondary data were source from scholarly publication. Descriptive statistics was used. The findings of this study revealed that the students had a medium to high degree of positive attitude toward knowledge sharing. The students had a positive perception of the use of knowledge sharing in supporting their education. The findings are essential for several stakeholders, such as university policymakers, lecturers, and the students, to provide a deeper understanding of knowledge sharing at the university education level. The findings may encourage policymakers at the university and the classroom levels to organize activities that promote knowledge sharing such as seminars, symposiums, or knowledge sharing exercises during the classroom hours to raise the students' knowledge sharing behavior and enhance education. The results of this study should be useful to policy makers at the university level and the classroom level as there is a positive attitude in disseminating knowledge in the higher educational setting.
\end{abstract}

Keywords: Knowledge Sharing, Accounting Education, Higher Education, Saudi Arabia

JEL Classification Code: D83

\section{Introduction}

Knowledge sharing is the essential component of knowledge management (Fengjie et al., 2004). Knowledge sharing is a process of exchanging resources from one person to another (Sharratt \& Usoro, 2003). Similarly, Williem (2003) claimed that knowledge sharing was a process through which valuable information was disseminated between two parties or more through a reciprocal process. As a result, knowledge sharing allowed for the reshaping and understanding of

\footnotetext{
*Acknowledgements:

This publication was supported by the Deanship of Scientific Research at Prince Sattam bin Abdulaziz University, Alkharj, Saudi Arabia.

${ }^{1}$ First Author. Lecturer, Accounting Department, College of Business Administration, Prince Sattam bin Abdulaziz University, Saudi Arabia.Email: o.bagais@psau.edu.sa

${ }^{2}$ Corresponding Author. Assistant Professor, Accounting Department, College of Business Administration, Prince Sattam bin Abdulaziz University, Saudi Arabia [Postal Address: Zayed bin Haretha Street, Al-Salam District, Al-Kharj, Al-Rayadh, 16244, Saudi Arabia] Email: k.aljaaidi@psau.edu.sa

${ }^{3}$ Professor, Accounting Department, College of Business Administration, Umm Al-Gura University, Saudi Arabia. Email: esmoataz@uqu.edu.sa

(c) Copyright: The Author(s)

This is an Open Access article distributed under the terms of the Creative Commons Attribution Non-Commercial License (https://creativecommons.org/licenses/by-nc/4.0/) which permits unrestricted non-commercial use, distribution, and reproduction in any medium, provided the original work is properly cited.
}

knowledge in a new context. Knowledge sharing can also be viewed as a group of behavior involving the interchange of information among individuals within an organization (Connelly \& Kelloway, 2003). Fengjie et al. (2004) specify that knowledge sharing involves individual, team, and organization since it aims at sharing information with the mentioned groups. Further, knowledge sharing could also be viewed as knowledge innovation because people include their perspective when sharing knowledge. Therefore, the more knowledge shared, the greater a high-quality innovation can be achieved. The upside of free knowledge sharing in an organization is that it increases its responsiveness and effectiveness and, thus, avoids time wastage when similar departments unknowingly solve the same issues (Marks et al., 2008). Further, Gwin (2003) argued that knowledge sharing was a component of the cycle of knowledge creation, sharing, and use. Knowledge sharing is also a process through which a mutual stock of knowledge is disseminated among groups or individuals through direct or indirect interactions (Yoo et al., 2007). Moreover, Shapira et al. (2006) claimed that knowledge sharing was the extent to which knowledge was shared. According to Birvham et al. (2005), knowledge sharing was the process through which knowledge was captured and moved from the source unit to the recipient unit. Notably, knowledge exists in not only documents but also in people's minds and is exhibited through their actions and behaviors (Al-Alawi et al., 2007). 
Issues arising from knowledge sharing have been examined in the organizational context because they are profit-driven, while the educational contexts have remained neglected (Hoa et al., 2020; Muafi, 2020; Ardichvili et al., 2003; Han \& Anantatmula, 2007; Lin, 2007a; Lin, 2007b; Riege, 2005). Similarly, there has been limited research on knowledge sharing in a classroom context (Wangpipatwong, 2009; Yaghi et al., 2011). Studies have shown that knowledge sharing is influenced by people's educational level whereby highly educated individuals are more inclined to share their knowledge because society perceived them as knowledgeable (Aamir et al., 2009). Further, Oosterlinck (2004) found that knowledge sharing assists students to receive additional feedback, which increases the chances of success in future research initiatives. Knowledge sharing among students regularly occurs when they share knowledge with their classmates during tutorials and laboratory sessions through study-related material, websites, sharing personal notes, databases, software, library resources, and personal collections (Yuen \& Majid, 2007). This study, thus, aims to explore the knowledge sharing attitudes among accounting students at Umm Al-Gura University for the academic year 2013-2014.

The remainder of the paper proceeds as follows. The next section briefly discusses the methodology. The third section highlights the findings of the study. And, the final section discusses the conclusion and implications.

\section{Research Methodology}

\subsection{Sample Selection and Procedures}

The study employed the sampling method to collect the necessary data from the sampling population. In particular, the researchers randomly selected participants that were best suited to achieve the goals of the study. The study was done at the College of Business Administration in the Accounting Department at Umm Al-Gura University, where participants responded to different questions. The research was designed by the team, while the respondents were students from the mentioned institution who were at the moment in their 2013-2014 academic year.

The researchers collected the data after class hours, but they had sought permission beforehand from the lecturers to conduct the study. The researcher first introduced themselves during lectures and provided a brief explanation of the purpose of the study. The students were allowed to fill the questionnaire throughout the week and, a week later, the researchers recollected the questionnaires. Finally, samples of 202 accounting students were used in the study.

The students' knowledge sharing attitudes were measured with three items. A 5-point Likert scale is used to measure the students' attitudes towards knowledge sharing $-1=$ "extremely disagree", $2=$ "disagree", $3=$ "neither agree nor disagree" 4 = "agree", and 5 = "extremely agree".

\subsection{Source of Data and Analysis}

This study used two sources of data collection, namely, secondary data and primary data. The secondary data are collected from the scholarly publications on the topic of knowledge sharing. As for the primary data, a selfadministered questionnaire was used. This questionnaire is adapted from Wangpipatwong (2009). 204 questionnaires were returned. Regarding the data analysis, this study used descriptive statistics to analyze the data collected such as frequency and percentage.

\section{Findings of the Study}

\subsection{Descriptive Statistics of the Respondents}

Table 1 depicts the demographic attributes of the respondents based on age, level of study and CGPA. It is worth mentioning that this study is conducted in the male section of the college due to the separation of the sexes.

Based on the demographic information depicted in Table 1, the majority of students $(70 \%)$ were between 21 and 24 years old. The highest number of students $(49 \%)$ were senior students. In terms of CGPA, the majority of students (52\%) obtained a cumulative grade point average between 2 and 3 .

Table 1: Demographic Attributes of the respondents

\begin{tabular}{|l|c|c|}
\hline $\begin{array}{l}\text { Demographic } \\
\text { characteristics }\end{array}$ & $\begin{array}{c}\text { Frequency } \\
(\mathbf{n}=\mathbf{2 0 4})\end{array}$ & $\begin{array}{c}\text { Percent } \\
\%\end{array}$ \\
\hline Age & & \\
\hline$<21$ & 26 & 13 \\
\hline $21-<24$ & 142 & 70 \\
\hline $24-<27$ & 28 & 14 \\
\hline $27-<30$ & 4 & 02 \\
\hline 30 and above & 2 & 01 \\
\hline Level of study & & \\
\hline Freshmen & 11 & 05 \\
\hline Sophomore & 40 & 20 \\
\hline Junior & 52 & 26 \\
\hline Senior & 99 & 49 \\
\hline CGPA & & \\
\hline$<1$ & 3 & 0.01 \\
\hline $1-<2$ & 35 & 0.17 \\
\hline $2-<3$ & 106 & 0.52 \\
\hline 3 and above & 58 & 0.29 \\
\hline
\end{tabular}


Omer Ali BAGAIS, Khaled Salmen ALJAAIDI, Ehsan Saleh AL-MOATAZ I

\subsection{Empirical Results}

This section of the study addresses the qualitative results of the study used to identify the knowledge sharing attitudes among the accounting students. The students were asked whether they usually inform their classmates of what they are working on. The students' attitudes towards this statement are depicted in Table 2.

Table 2 shows that 78 respondents $(38.6 \%)$ have not determine their inclination towards knowledge sharing, $71(35.1 \%)$ have a positive attitude towards knowledge sharing, and $53(26.2 \%)$ show a negative attitude towards knowledge sharing. These results illustrate a positive perception of the accounting students towards informing their classmates about what they are working on. When comparing the degree of agreement with the degree of disagreement, it turns out that the agreement level outweighs the disagreement level by $25 \%$.

The students were also asked to indicate their attitudes about the extent to which they usually share the new knowledge they acquire with their classmates. The students' attitudes towards this statement are exhibited in Table 3.

Table 3 shows that 88 respondents $(43.6 \%)$ have a positive attitude towards knowledge sharing, 77 (38.1\%) have showed neither a positive nor a negative attitude towards knowledge sharing, and 37 (18.4\%) showed a negative attitude towards knowledge sharing. This result demonstrates in general a positive perception of the accounting students towards sharing new knowledge they acquire with their classmates. As a comparison is conducted between agreement and disagreement degrees, the agreement level towards this item outweighs the disagreement level by $58 \%$.

The students were also asked to report their perception towards whether they always tell their classmates whatever they know when they are asked. The students' attitudes towards this statement are depicted in the following Table 4.

Table 2: I usually inform my classmates of what I am working on

\begin{tabular}{|l|c|c|}
\hline Scale & $\begin{array}{c}\text { Frequency } \\
\text { (n= 202) }\end{array}$ & $\begin{array}{c}\text { Percent } \\
\%\end{array}$ \\
\hline Extremely disagree & 15 & 7.4 \\
\hline Disagree & 38 & 18.8 \\
\hline Neither agree nor disagree & 78 & 38.6 \\
\hline Agree & 51 & 25.2 \\
\hline Extremely agree & 20 & 9.9 \\
\hline Total & 202 & 100 \\
\hline
\end{tabular}

Table 3: I usually share with my classmates the new knowledge that I acquire

\begin{tabular}{|l|c|c|}
\hline Scale & $\begin{array}{c}\text { Frequency } \\
(\mathbf{n = 2 0 2})\end{array}$ & $\begin{array}{c}\text { Percent } \\
\%\end{array}$ \\
\hline Extremely disagree & 9 & 4.5 \\
\hline Disagree & 28 & 13.9 \\
\hline Neither agree nor disagree & 77 & 38.1 \\
\hline Agree & 66 & 32.7 \\
\hline Extremely agree & 22 & 10.9 \\
\hline Total & 202 & 100 \\
\hline
\end{tabular}

Table 4: I always tell my classmates whatever I know when they ask me

\begin{tabular}{|l|c|c|}
\hline Scale & $\begin{array}{c}\text { Frequency } \\
\text { (n= 202) }\end{array}$ & $\begin{array}{c}\text { Percent } \\
\text { \% }\end{array}$ \\
\hline Extremely disagree & 4 & 2.0 \\
\hline Disagree & 10 & 5.0 \\
\hline Neither agree nor disagree & 28 & 13.9 \\
\hline Agree & 75 & 37.1 \\
\hline Extremely agree & 85 & 42.1 \\
\hline Total & 202 & 100 \\
\hline
\end{tabular}

Table 4 shows that 160 respondents (79.2\%) have a positive attitude towards knowledge sharing, 28 (13.8\%) have a neutral attitude, and 14 (7\%) show a negative attitude toward telling their classmates about whatever they know when asked. Comparing between the agreement and disagreement degrees, it turns out that the agreement level outweighs the disagreement level by $91 \%$.

Tables 2, 3, and 4 show that the frequencies and percentages of the respondents' agreements degrees outweigh the disagreements' levels. The highest level of agreement is given to the item $(79.2 \%)$ stating "I always tell my classmates whatever I know when they ask me," followed by the item $(49.6 \%)$ stating "I usually share with my classmates the new knowledge that I acquire," finally by the item (38.6\%) stating "I usually inform my classmates of what I am working on" as shown in Table 5.

The mean scores of the three items of knowledge sharing are calculated and showed in Table 6:

Before analyzing Table 6, it is worth to mention that the five-point Likert Scale of the three items is converted into three levels of agreement, namely; high, medium and low as shown in the following Table 7: 
Table 5: Percentage of agreement levels and rankings

\begin{tabular}{|l|c|c|c|}
\hline Scale & $\begin{array}{c}\text { Frequency } \\
\text { (n= 202) }\end{array}$ & $\begin{array}{c}\text { Percent } \\
\%\end{array}$ & Rank \\
\hline $\begin{array}{l}\text { I always tell my } \\
\text { classmates whatever I } \\
\text { know when they ask me }\end{array}$ & 160 & $79.2 \%$ & 1 \\
\hline $\begin{array}{l}\text { I always tell my } \\
\text { classmates whatever I } \\
\text { know when they ask me }\end{array}$ & 88 & $49.6 \%$ & 2 \\
\hline $\begin{array}{l}\text { I usually share with } \\
\text { my classmates the } \\
\text { new knowledge that I } \\
\text { acquire }\end{array}$ & 78 & $38.6 \%$ & 3 \\
\hline
\end{tabular}

Table 6: Mean scores and rankings

\begin{tabular}{|l|c|c|c|c|}
\hline Scale & Mean & SD & $\begin{array}{c}\text { Level of } \\
\text { agreement }\end{array}$ & Rank \\
\hline $\begin{array}{l}\text { I always tell } \\
\text { my classmates } \\
\text { whatever I know } \\
\text { when they ask me }\end{array}$ & 4.12 & .962 & High & 1 \\
\hline $\begin{array}{l}\text { I always tell } \\
\text { my classmates } \\
\text { whatever I know } \\
\text { when they ask me }\end{array}$ & 3.32 & .992 & Medium & 2 \\
\hline $\begin{array}{l}\text { I usually } \\
\text { share with my } \\
\text { classmates the } \\
\text { new knowledge } \\
\text { that I acquire }\end{array}$ & 3.11 & 1.061 & Medium & 3 \\
\hline $\begin{array}{l}\text { Overall - } \\
\text { Knowledge } \\
\text { sharing }\end{array}$ & 3.52 & .783 & Medium & n/a \\
\hline
\end{tabular}

Table 7: Level of agreements' scores

\begin{tabular}{|l|c|c|}
\hline No. & Score & Level of agreement \\
\hline 1 & $1-2.33$ & Low \\
\hline 2 & $2.34-3.67$ & Medium \\
\hline 3 & $3.68-5$ & High \\
\hline
\end{tabular}

Table 8: Overall knowledge sharing frequency

\begin{tabular}{|l|c|c|}
\hline Scale & $\begin{array}{c}\text { Frequency } \\
(\mathbf{n = 2 0 2})\end{array}$ & $\begin{array}{c}\text { Percent } \\
\%\end{array}$ \\
\hline $\begin{array}{l}\text { High degree of a positive } \\
\text { attitude towards knowledge } \\
\text { sharing }\end{array}$ & 72 & 35.6 \\
\hline $\begin{array}{l}\text { Medium degree of a positive } \\
\text { attitude towards knowledge } \\
\text { sharing }\end{array}$ & 105 & 52 \\
\hline $\begin{array}{l}\text { Low degree of a positive } \\
\text { attitude towards knowledge } \\
\text { sharing }\end{array}$ & 25 & 12.4 \\
\hline Total & 202 & 100 \\
\hline
\end{tabular}

As shown on Table 6 the highest mean score was (4.12), which is considered a high level of agreement for the item stating "I always tell my classmates whatever I know when they ask me," the second rank of mean score was (3.32), which is deemed a medium degree of agreement for the item stating "I always tell my classmates whatever I know when they ask me," and the third rank of mean score was (3.11), which reflected a medium agreement for the item stating "I usually share with my classmates the new knowledge that I acquire." As for the overall ranking of knowledge sharing as a composite factor, the mean score was (3.52), which reflects a medium agreement of the students towards knowledge sharing in general. Therefore, the results indicate that accounting students have a medium to high level of positive attitude towards knowledge sharing. Supporting this, the overall knowledge sharing factor is converted into the three level scores of agreements as shown on Table 8 .

The overall knowledge sharing has a medium level of agreement as the majority of the respondents $105(52 \%)$ are ranked in the medium score of agreement, followed by the high level of agreement $72(35.6 \%)$. This result indicates that accounting students at Umm Al-Gura University have a medium to high level of positive attitude towards knowledge sharing.

\section{Conclusion and Implication}

The study explored knowledge sharing among 202 accounting students at Umm Al-Gura University in session during the 2013-2014 academic year. The findings of this study revealed that the students had a medium to high degree of positive attitude toward knowledge sharing. The results indicated that the students had a positive perception of the use of knowledge sharing in supporting their education. 
These findings are essential for several stakeholders, such as university policymakers, lecturers, and the students. The stakeholders will get a deeper understanding of knowledge sharing at the university education level. The findings may encourage policymakers at the university and the classroom levels to organize activities that promote knowledge sharing such as seminars, symposiums, or knowledge sharing exercises during classroom hours to raise the students' knowledge sharing behavior and enhance education.

The study has various notable limitations. One of the limitations was that the number of respondents was smaller and only in the single department of accounting. Future studies should consider larger numbers of respondents across different departments within the college of business or other medical and engineering colleges. In addition, the study focused on a single measurement of knowledge. Specifically, this study adopted the knowledge sharing measurement method borrowed from Wangpipatwong (2009). Future studies should consider other measurements of knowledge sharing with a larger number of items or different composite measurements.

\section{References}

Al-Alawi, A. I., Al-Marzooqi, N. Y., Mohammed, Y. F. (2007). Organisational culture and knowledge sharing: Critical success factors. Journal of Knowledge Management, 11(2), 22-42.

Ardichvili, A. (2008). Learning and knowledge-sharing in virtual communities of practice. Advances in Developing Human Resources, 10(4), 541-554.

Ardichvili, A., Page, V., \& Wentling, T. (2003). Motivation and barriers to participation in virtual knowledge-sharing communities of practice. Journal of Knowledge Management, 7(1), 64-77.

Bircham-Connolly, H., Corner, J., \& Bowden, S. (2005). An empirical study of the impact of question structure on recipient attitude during knowledge sharing. Electronic Journal of Knowledge Management, 32(1), 1-10.

Chen, J., Koch, P., Chung, M., \& Lee, C. (2007). Exploring contributory factors in student-to-student knowledge sharing: A Singaporean perspective. Paper presented at the annual meeting of the NCA 93rd Annual Convention, November 14, 2007, TBA, Chicago, IL.

Cheng, M. Y., Ho, J. S. Y., \& Lau, P. M. (2009). Knowledge sharing in academic institutions: a study of Multimedia University Malaysia. Electronic Journal of Knowledge Management, 7(3), 313-324.

Cho, N., Li, G. Z., \& Su, C. -Z. (2007). An empirical study on the effect of individual factors on knowledge sharing by knowledge type. Journal of Global Business and Technology, 3(2), 1-15.

Connelly, C. E., \& Kelloway, E. K. (2003). Predictors of employees' perceptions of knowledge sharing cultures. Leadership \& Organization Development Journal, 24(5), 294-301.
Fengjie, A., Fei, Q., \& Xin, C. (2004). Knowledge sharing and web-based knowledge-sharing platform. In: IEEE International Conference on E-Commerce Technology for Dynamic E-Business, 2004 (pp. 278-281). IEEE.

Gwin, C. (2003). Sharing knowledge: innovations and remaining challenges: an OED evaluation. Washington, DC: World Bank. https://openknowledge.worldbank.org/handle/10986/15043

Han, B. M., \& Anantatmula, V. S. (2007). Knowledge sharing in large IT organizations: A case study. The Journal of Information and Knowledge Management Systems, 37(4), 421-439.

Hoa, N. D., Thanh, V. B., Mai, V. T., Tung, L. V., \& Quyen, H. V. T. (2020). Knowledge Sharing Influence on Innovation: A Case of Textile and Garment Enterprises in Vietnam. Journal of Asian Finance, Economics, and Business, 7(7), 555-563. https://doi. org/10.13106/jafeb.2020.vol7.no7.555

Lin, C. P. (2007a). To share or not to share: modeling knowledge sharing using exchange ideology as a moderator. Personnel Review, 36(3), 457-475.

Lin, H. F. (2007b). Effects of extrinsic and intrinsic motivation on employee knowledge sharing intentions. Journal of Information Science, 33(2), 135-149.

Marks, P., Polak, P., McCoy, S., \& Galletta, D. (2008). Sharing knowledge. Communications of the ACM, 51(2), 60-65.

Muafi, M. (2020). A Nexus among Strategic Orientation, Social Network, Knowledge Sharing, Organizational Innovation, and MSMEs Performance. Journal of Asian Finance, Economics, and Business, 7(6), 327-338. https://doi.org/10.13106/ jafeb.2020.vol7.no6.327

Oosterlinck, A. (2004). The modern university and its main activities. Reinventing the research university, 119 .?

Riege, A. (2005). Three-dozen knowledge-sharing barriers managers must consider. Journal of Knowledge Management, 9(3), 18-35.

Shapira, P., Youtie, J., Yogeesvaran, K., \& Jaafar, Z. (2006). Knowledge economy measurement: Methods, results and insights from the Malaysian Knowledge Content Study. Research Policy, 35(10), 1522-1537.

Wangpipatwong, S. (2009). Factors influencing knowledge sharing among university students. In: Proceedings of the 17th International Conference on Computers in Education.

Willem, A. (2003). The role of organization specific integration mechanisms in inter-unit knowledge sharing. PhD Dissertation, Vlerick Leuven Gent Management School, Ghent University, Belgium. http://72.14.203.104/search?q=cache:AwAf_ok1x7UJ

Yaghi, K., Barakat, S., Alfawaer, Z. M., Shkokani, M., \& Nassuora, A. (2011). Knowledge sharing degree among the undergraduate students: a case study at applied science private university. International Journal of Academic Research, 3, 20-4.

Yoo, Y., Lyytinen, K., \& Heo, D. (2007). Closing the gap: towards a process model of post-merger knowledge sharing. Information Systems Journal, 17(4), 321-347.

Yuen, T. J., \& Majid, M. S. (2007). Knowledge-sharing patterns of undergraduate students in Singapore. Library Review, 56(6), 485-494. 